memorial theatre set in a well-maintained park. But what was particularly intriguing was a visit to a jade factory. I had never previously appreciated the expertise that goes into the carving of jade nor, for that matter, the inherent dangers of the work: one slip, one lapse of concentration, when working with those evil looking high-speed lathes could so easily result in the operative leaving the factory with a finger or two fewer than when he entered. All in all, the price asked for the finished product was by no means excessive. The same, incidentally, could be said of the Chinese cloisonné work, the manufacture of which we had seen as part of our Shanghai tour. A pity it is that I don't particularly like either.

\section{Reflections in a Chinese mirror}

It would be monstrously presumptuous to draw conclusions about a country as vast and as complex as the People's Republic of China after such a fleeting visit. A few reflections are all that are allowed.

China as it is today-and it is patently still in a state of transition following the relatively recent political upheavals, and in particular, the insanity of the Cultural Revolution-is not for the hedonist, the fashion-conscious, the gourmet, the culture-vulture, the sophisticate, the cold-sensitive, the bronchitic and for those intolerant of a rigid, hide-bound bureaucracy. Nevertheless, one cannot fail to be deeply impressed by the positive host-like qualities of its people; the courtesy and the courtesies; the generosity and the hospitality, as witness the succession of banquets given in our honour. Nor could one fail to be impressed by the warmth of the welcome accorded to us wherever we visited. Prominently displayed, for example, on black-boards in the entrance to each hospital was a message of welcome in English, sometimes a little quaint, such as the one which read, 'Welcome to the Loyal College of Psychiatrists'. What, too, was especially touching was the way in which, even in the back wards the chronic patients were capable of lifting themselves out of their psychoses momentarily and clapping our entrances and our exits. For me personally, however, the most poignant experience was the brief encounter with my little Princess at the Children's Palace in Shanghai.

For all of us, I feel sure, it was an unforgettable adventure, one that I, at any rate, would not have missed-not for all the tea in China.

\title{
An Appeal for Dr Anatoly Koryagin to the Medical Profession
}

Dr Anatoly Koryagin, who was recently elected to the Fellowship of the College (Bulletin, April 1985, 9, 80), is still languishing in Chistopol Prison. Recently an appeal for him was smuggled out to the West from a friend who prefers to remain anonymous for fear of reprisal.

'Protesting about psychiatric abuse isn't fashionable in the West nowadays, so no one will intercede for you. I advise you to think about your future and your family ...'These words have been used by a KGB investigator as a surprisingly primitive method of inducement to recant.

Anatoly Koryagin is a psychiatrist. He was regarded as a good specialist. He practised in a clinic and had a Candidate of Science degree (equivalent to a western $\mathrm{PhD}$ ), published his articles in specialist journals, and delivered papers at scientific conferences. But could many psychiatrists be found who wanted to check out whether everything was in order regarding their own science in the USSR. I can answer that question: in the last eight years, only two.

One was Alexander Voloshanovich, who has emigrated and practises psychiatry in England. The other is Anatoly Koryagin, who is slowly dying in the strict-regime prison of Chistopol.

Anatoly Koryagin has once again declared a hunger strike. We've already lost count which one this is-his third? Or his fourth? Now Dr Koryagin is protesting against the conditions in Chistopol Prison: against the virtually complete absence of medical care; against the use of the punishment cells for the smallest 'transgression'; against the soup which even the pigs wouldn't touch ...

So please listen, those who've been lucky enough to be born in democratic countries! Anatoly Koryagin was brutally beaten in prison. He has become bloated from starvation and can now no longer get out of his bed. He has said that he will continue his strike until the end of his prison term-that means until February 1988. Will he survive till then? A 'humane' Soviet law says: 'Punishment must not harm the health of prisoners.' So hunger strikers are artificially (more accurately-forcibly) fed. There are no words to describe the pain and humiliation involved in this. Andrei Dmitrievich Sakharov, according to his relatives' reports, ended his hunger strike last year after one month: 'It was too torturous', he explained. Anatoly Koryagin has been on hunger strike continuously for almost a year and his family is suffering dreadfully in Kharkov.

I appeal to all the doctors of the world, and also to each of you individually. Today your colleague, the doctor Koryagin, is near to death because of his loyalty to the Hippocratic Oath. Today he and his family need your immediate help. Tomorrow it may be too late. I ask you to do everything possible to secure the immediate emigration of Anatoly Koryagin and his family from the USSR.

I suggest that as this can't be done by normal means, you make the Koryagin family's immediate emigration an absolute condition of any co-operation with the health organization of the USSR. They'll say to you: 'That's not humane; that's going against your duty as a doctor ... . Be ready to be accused of 'fascism' and other contemptible things. Our medicine, as everyone knows, is the most humane in the world. Probably that's why the doctors in Soviet 'correctional' camps don't excuse ill prisoners from work. Probably that's why-as 'punishment'-in the same camps prisoners are put in unheated punishment cells and virtually not fed. And doctors sanction this!

Even if I wrote an article long enough to fill a whole page of a newspaper, I wouldn't have room to list all the crimes of these 'doctors'. They couldn't even care less about the health of the 'free' citizen of this country, so is it likely they'll care about prisoners? But let me return to the main point.

You have a real chance to save a human life. Your doctor's duty is to do everything possible to that end, whatever the price.

And please remember one more thing. The fact that I am writing to you now with this appeal is extremely dangerous for me too, and for my family. It would be very sad if I am taking this risk in vain, if I don't succeed in stirring your hearts.

Individual members of the College may wish to write to $\mathrm{Dr}$ Anatoly Koryagin at USSR 422950, Tatarskaya ASSR, g. Chistopol, uchr. U3-148/st-4; and also the Governor of Chistopol Prison, Captain Romanov, Tatarskaya, USSR. 